James Madison University JMU Scholarly Commons

Libraries

Libraries

Spring 4-18-2018

\title{
The Discoverability of Award-Winning Undergraduate Research in History: Implications for Academic Libraries
}

Jody C. Fagan

James Madison University, faganjc@jmu.edu

Malia Willey

James Madison University, willeyme@jmu.edu

Follow this and additional works at: https://commons.lib.jmu.edu/letfspubs

Part of the History Commons, Scholarly Communication Commons, and the Scholarly Publishing Commons

\section{Recommended Citation}

Fagan, Jody C. and Willey, Malia, "The Discoverability of Award-Winning Undergraduate Research in History: Implications for Academic Libraries" (2018). Libraries. 105.

https://commons.lib.jmu.edu/letfspubs/105 


\title{
The Discoverability of Award-Winning Undergraduate Research in History: Implications for Academic Libraries
}

Running Head: Discoverability of Undergraduate Research in History

Author Information:

Jody Condit Fagan (faganjc@jmu.edu), http://orcid.org/0000-0003-2861-3477

Malia Willey (willeyme@jmu.edu), http://orcid.org/0000-0003-4994-4136

Libraries \& Educational Technologies

James Madison University

Harrisonburg, VA 22807

This is an Accepted Manuscript of an article published by Taylor \& Francis in College \& Undergraduate Libraries on 4/18/2018, available online: 10.1080/10691316.2018.1456994.

\begin{abstract}
Making scholarly information visible to web search engines is an ongoing challenge, and undergraduate research is no exception. Using a sample of award-winning undergraduate history papers and journals, the authors searched Google, Google Scholar, Microsoft Academic, and the authors' institutional repository to gauge the difficulty of locating these works. Given that many of these works were not easily found, results suggest that libraries and their institutions could be doing more to increase the discoverability of undergraduate research. Based on the success stories observed in this study, we offer strategies to libraries and librarians for increasing the visibility of undergraduate student research.
\end{abstract}

Keywords: undergraduate research; history; visibility; institutional repositories; student journals; search engine optimization 


\section{Introduction}

Undergraduate research is becoming more ubiquitous in higher education, and students in the field of history are increasingly participating in undergraduate research. Award-winning history papers are evidence of exemplary scholarship by undergraduate students. While it is clear that undergraduate students are producing praiseworthy research, the discoverability of their work is unknown. How often can scholarly articles by undergraduate researchers be located online? Where are full-text examples of commendable undergraduate research in history found? Academic libraries already play an active role in supporting undergraduate research. Could the role of academic librarians in the undergraduate research process be further strengthened by promoting the dissemination and visibility of research by undergraduate students? This paper investigates the web visibility of award-winning history papers written by undergraduate students, and then more broadly considers the implications for academic libraries and librarians. What strategies can librarians use to make the contributions of undergraduate researchers to the scholarly community more visible?

\section{Literature Review}

The Boyer Commission on Educating Undergraduates in the Research University recommended research-based learning for undergraduate students in the 1998 report, Reinventing Undergraduate Education: A Blueprint for America's Research (15). Since the publication of this influential report, interest in undergraduate research by institutions of higher education has increased (Katkin 2003). The Council on Undergraduate Research (CUR) defines undergraduate research as "an inquiry or investigation conducted by an undergraduate student that makes an original intellectual or creative contribution to the discipline" (n.d., n.p.). Undergraduate research 
is now recognized as a high-impact educational practice for students at colleges and universities (Association of American Colleges \& Universities 2008).

Several challenges to supporting undergraduate research in the discipline of history have been identified. Humanists, particularly historians, have been slower to lead efforts in undergraduate research than scholars in other disciplines (Corley 2013). Some faculty in the humanities prefer solitary work rather than the collaborative nature of undergraduate research (Stephens and Thumma 2005; Crawford and Shanahan 2014). Other cultural barriers to undergraduate research in history include the perceptions that legitimate historical research commences at the graduate level and that students may not want to engage in an inquiry-based experience (Stephens and Thumma 2005). Lack of incentives and compensation exist as structural barriers for both faculty and student participation in undergraduate research (Stephens and Thumma 2005).

Despite the aforementioned challenges, interest in undergraduate history research is starting to grow. Many history majors are now required to complete a research-based project as part of the curriculum (Jones et al. 2012). The literature offers several instances of historians successfully engaging in the research with undergraduate students. Students and a professor have worked to collaboratively produce a research paper in a seminar on legal history at Davidson College (Wertheimer 2002). A professor and undergraduate student at Virginia Tech developed a module on the global events of 1968 as a part of a digital history project funded by the National Endowment for the Humanities (Stephens and Thumma 2005). Also at Virginia Tech, essays written by senior history majors in the capstone seminar are published in an edited book (Stephens, Jones, and Barrow 2011). Through a grant for faculty members, a professor mentored four students through an archival project in Belgium to create a database of unpublished tax 
records (Johnson and Harreld 2012). A historian at Minnesota State University has recruited several students to collaborate on research using materials photographed at archives in France (Corley 2013). There are also examples of historians and librarians partnering together to support students in their research (Cook 2015; Daniel 2012; Hicks and Howkins 2015).

Students participating in undergraduate research produce scholarship that contributes to scholarly discourse. The Boyer Commission (1998) identified dissemination as an "essential and integral part of the research process" (24). Three common models for increasing the visibility of capstone research by history majors are public presentations, portfolios, and undergraduate student journals (Jones et al. 2012). Digital history projects now offer another platform for students to share their work with the world in a creative manner (Harbinson and Waltzer 2013; Lawrence 2013). Research manuals for history majors suggest students consider presenting at conferences or publishing articles (Galgano, Arndt, and Hyser 2013; Presnell 2013).

Publication of historical scholarship in an academic journal by students is an ambitious achievement. Galgano, Arndt, and Hyser (2013) instruct students, "Publication opens our research to a potentially global audience, and it is enduring. If your work is accepted and published, it exists forever" (152). Accepted submissions go through a review process that indicates an unusually high quality of work by undergraduate students. Benefits to undergraduates who publish in a journal include increased autonomy and confidence, the ability to communicate according to the standards of a discipline, and the experience of the review process for academic papers (Spronken-Smith et al. 2013, 109).

Academic libraries have begun to support undergraduate research in a variety of ways. While librarians have long facilitated research by students, Stamatoplos (2009) urged librarians to specifically consider the needs of those engaging in undergraduate research experiences 
independent of coursework. He advocated, 'Librarians need to support these students' essential needs to acquire and build upon previous scholarship, to help them to work effectively in such contexts and add to the body of scholarship" (Stamatoplos 2009, 245). In a survey of students who were mentored on a research project in the arts, humanities, or social sciences at Hope College, a majority of students identified sources, services, equipment, and spaces as multiple ways that the library affected their experience (Wiebe 2016, 244). A study by Hensley, Shreeves, and Davis-Kahl (2014) serves a benchmark of how libraries are supporting formal undergraduate research programs. The range of library support includes instruction, space, dissemination, awards, collections, extended loan periods, publishing support, and the design and printing of research posters and publications (Hensley, Shreeves, and Davis-Kahl 2014, 430). Instruction is the most prevalent form of support for undergraduate research programs (Hensley, Shreeves, and Davis-Kahl 2014). A subsequent study by Hensley (2015) found database searching was the most common topic of information literacy instruction for undergraduate research programs, but the author identified a growing emphasis on instruction related to scholarly communication practices.

Libraries have begun specific efforts to bolster the dissemination of undergraduate research and promotion of their visibility as scholars. Students with participation in the scholarly communication process reported less than moderate confidence in their knowledge of author and publishing rights and publication and access models (Fraser Riehle and Hensley 2017, 163). Librarians can engage students in topics related to scholarly communication, such as creator rights and open access (Davis-Kahl 2012). Indeed, work by librarians on the intersection of information literacy and scholarly communication has expanded (Fraser Riehle and Hensley 2017). An undergraduate research training program at the University of Tennessee, Knoxville 
teaches students about outlets for sharing their work, including academic publications and institutional repositories (Douglass and Mack 2015). Caprio (2014) has recognized undergraduates as emergent authors and has encouraged libraries to further support student publishing. Academic libraries are often poised to facilitate undergraduate publication through their expertise, services, infrastructures, and partnerships (Weiner and Watkinson 2014). Many libraries have implemented electronic theses and dissertations programs (Wang, Bulick, and Muyumba 2014). Yet sometimes undergraduates remain on the fringes of who is considered among scholars: a comprehensive literature review of scholarly use of social media and altmetrics included graduate students, but not undergraduates (Sugimoto et al. 2017). Institutional repositories are an online venue where students can distribute their scholarship, such as capstones, theses, and undergraduate publications (Caprio 2014). A study by Stone and Lowe (2014) of undergraduate theses held in digital institutional repositories found that these works are being cited in refereed journals, dissertations, and other theses. In addition to libraries hosting undergraduate research, some librarians serve as managers or collaborative managers of undergraduate research journals, which may or may not be included in the institutional repository (Farney and Byerley 2010; Weiner and Watkinson 2014; Johnson, Mears, and Drescher 2017). Farney and Byerley (2010) described how using Open Journal Systems (OJS) for hosting undergraduate journals allows Google Scholar to easily index content. Fully one-quarter of online visitors to Undergraduate Research Journal at UCCS (University of Colorado at Colorado Springs) access the journal via a web search engine (Farney and Byerley 2010, 328). Many papers from the journal's first two issues have been viewed over 350 times (Farney and Byerley 2010, 328). 
The widest dissemination of research, including undergraduate student research, depends on public search engines. As the web has evolved, scholars from all disciplines have begun using search engines for research (Van Noorden 2014). Several studies testify to the use of Google and Google Scholar by humanities scholars specifically (Inger and Gardner 2016; Kemman, Kleppe, and Scagliola 2013; Martin and Quan-Haase 2016; Van Noorden 2014), despite the uncertainty surrounding coverage of humanities scholarship in web search engines (Fagan 2017).

Despite using web search engines for research, humanities scholars seem slower than those in other disciplines to make their scholarly selves visible on the public web. The sciences and social sciences have focused on citation frequency and other scholarly performance indicators as motivators (Ebrahim et al. 2013; Ward, Bejarano, and Dudás 2015), which may be of less interest or utility in the humanities (Gumpenberger et al. 2016; Hammarfelt 2014; Hammarfelt 2016; Zuccala 2016). Other motivators may be more cogent: for example, Dagienè and Krapavickaitè (2016) reported humanities scholars believe listing research activities online improves public awareness. Interviews by Wu, Stvilia, and Lee (2017) suggest that identifying oneself on the public web can support finding relevant literature and other researchers, improving dissemination of research, and interactions with peers.

Although search engine optimization (SEO) of undergraduate research is not specifically addressed, librarians and information scientists often lead efforts to increase general discoverability of scholarly publications on the public web. For example, Gasparotto (2014) and Lee et al. (2016) described SEO strategies for improving discovery of online scholarly bibliographies. Ever since Arlitsch and O’Brien's (2012) study found low indexing of institutional repositories in Google Scholar, studies have investigated the presence of institutional repositories in Google or Google Scholar. Fagan (2017) has provided a full 
discussion of recommendations for improvement. Metadata experts are working to improve metadata in institutional repositories (Steele and Sump-Crethar 2016; Yang 2016b) and introduce semantic web standards into institutional repositories to support discovery (Hilliker, Wacker, and Nurnberger 2013). To make articles more findable, librarians can advise on collecting standard metadata and obtaining digital object identifiers (DOIs) (Johnson, Mears, and Drescher 2017). However, as recently as 2016, search engines are still struggling to discover PDFs and sometimes metadata in institutional repositories (Yang 2016a).

In light of the increasing interest among librarians and higher education institutions concerning undergraduate research, this study investigated the web visibility of award-winning undergraduate research papers in history, as well as their associated scholars, undergraduate journals, and institutional repositories.

\section{Methodology}

\section{Sample}

This research involved four samples: 1) 15 award-winning student papers; 2) the 22 authors and faculty advisors of those papers; 3) 14 undergraduate history journals; and 4) the 19 institutional repositories associated with the entities in the other samples. The first sample identified was that of the student papers (see Appendix). Each year, the American Historical Association (AHA) offers the Raymond J. Cunningham Prize for the best article published in a history department journal written by an undergraduate student (American Historical Association 2017). Similarly, Phi Alpha Theta and the World History Association (WHA) annually award an undergraduate and graduate student paper prize (unrelated to journals) (World History Association 2017). The 15 winners of these two awards since 2010 formed our sample of papers. Recent WHA award-winners were not identified on the site as graduate or undergraduate 
students, so web searches were performed to ascertain which winner was an undergraduate. In one case (McDonough-Tranza) the student's status could not be verified, and his paper was not included in the sample. The seven AHA papers appeared in five journals, and one WHA paper appeared in one of the same five journals. To this we added all the active history journals listed on the CUR website, resulting in a total sample of 14 journals.

\section{Procedure}

The researchers both searched for the article titles in the tools Google (https://www.google.com/), Google Scholar (https://scholar.google.com/), Microsoft Academic (https://academic.microsoft.com/), America: History and Life, Historical Abstracts, and the institution's repository. For each tool, we used a title search (no quotes), and a keyword search using the most unusual words from the title. The keyword search was not intended to replicate a user's search but was simply a second attempt to find the paper. Thus, all papers were searched for twice by both researchers.

For each paper, we recorded:

- the total number of results retrieved

- the result list ranking(s)

- whether the paper could be found in full text by the public (i.e., we did not use our institutional link resolver)

- the full-text sources, if any

- notes of interest.

We reviewed the top 10 results for each search tool. We defined a "hit" as a structured metadata record for the paper (e.g., a catalog or institutional repository record) or the full text of the paper. In Google Scholar, any type of result was considered a "hit." In Google, sometimes a "result" 
has links nested underneath the main result, and in Google Scholar, sometimes a "result" has multiple versions (via a link "All X Versions"). We did not count such subsidiaries as a "result" when enumerating their rank, but did explore whether subsidiary links led to a "hit" because the full-text version is not always the visible one (Fagan 2017; Pitol and DeGroote 2014). We numbered the results $1-10$, and any subsidiary links were given a decimal $(1.1,1.2,1.3)$. We opened PDF links to be sure the PDF was actually accessible.

We searched for author profiles for the students and AHA advisors in ORCID and Google Scholar by entering their full name as it appeared on the award website, and then we searched for variants of their name (for example, excluding middle initials). We also included the names of faculty advisors of AHA award-winning students in this study because we were curious to see if advisors' own practices had influenced their students.

For each journal, we searched for the journal title in the search tools, plus Ulrich's Periodical Directory and Facebook. In addition to recording where the journal could be found, we also noted the URL of the associated institution's repository and the date of the last Facebook post, if available. For Google Scholar, we used the "Return articles published in" feature available in the drop-down menu in Google Scholar. This feature appears to be the equivalent of the "publication" box in America: History and Life and Historical Abstracts.

Finally, we created a list of institutional repositories associated with either the papers or the journals, and noted the institutional repository software used, whether the institution's journal could be searched or browsed in the institutional repository, and whether the institutional repository contained other undergraduate research. 


\section{Results}

Google Scholar and Microsoft Academic results may link directly to full text, metadataonly records, or both. Although we had planned to count both metadata records and full-text results as "hits," this turned out to be an unnecessary detail for this sample: full text was available for all "hits." Specifically, eight of the fifteen papers could be found in full text. If full text was available somewhere, Google always found it. Google Scholar only found four of the eight full-text papers, three of which were on a departmental journal website and one of which was in an institutional repository. Of the four Google Scholar did not find, two were on the journal website, one was in the institutional repository, and one was on the magazine platform issuu (https://issuu.com/about). Searching on the title versus keywords made almost no difference in retrieval or ranking in Google or Google Scholar. One exception was Antiglio (2014-2015 WHA award), for which only a title search worked in Google; using keywords did not retrieve the article. Microsoft Academic found two of the full-text papers, both on the Chapman University departmental journal site. However for one of the papers, (Giczy, 2010 AHA award), only a title search worked in Microsoft Academic; using keywords did not retrieve the article. Two papers were found full text in their institution's institutional repository, however only when using keyword searching; literal title searches for Welker's paper (2015 AHA award) and Wemer's paper (2013 AHA award) returned no results. In all but one case, the found papers were ranked as the first result in Google, Google Scholar, Microsoft Academic, and the institutional repositories for at least one of the searches (title or keyword). The two research databases, America: History and Life and Historical Abstracts, contained none of the papers in the sample (see Table 1). 
Table 1. Which papers were found?

\begin{tabular}{lllllll}
$\begin{array}{l}\text { Author and Award } \\
\text { Year }\end{array}$ & Google & $\begin{array}{l}\text { Google } \\
\text { Scholar }\end{array}$ & $\begin{array}{l}\text { Microsoft } \\
\text { Academic }\end{array}$ & $\begin{array}{l}\text { America: } \\
\text { History \& } \\
\text { Life }\end{array}$ & $\begin{array}{l}\text { Historical } \\
\text { Abstracts }\end{array}$ & $\begin{array}{l}\text { Institutional } \\
\text { Repository }\end{array}$ \\
\hline Creech 2016* & No & No & No & No & No & No \\
\hline Schrottman 2015-16 & No & No & No & No & No & No \\
\hline Welker 2015* & Yes & No & No & No & No & Yes \\
\hline Antiglio 2014-15 & Yes & No & No & No & No & No \\
\hline Anbinder 2014* & Yes & Yes & No & No & No & No \\
\hline $\begin{array}{l}\text { Mscichowski 2013- } \\
14\end{array}$ & No & No & No & No & No & No \\
\hline Wallin 2013-14 & No & No & No & No & No & No \\
\hline Wemer 2013* & Yes & Yes & No & No & No & Yes \\
\hline Shah 2012-13 & Yes & Yes & Yes & No & No & No \\
\hline Valone 2012* & No & No & No & No & No & No \\
\hline Kang 2011-12 & Yes & No & No & No & No & No \\
\hline Williford 2011* & Yes & No & No & No & No & No \\
\hline Hood 2010-11 & No & No & No & No & No & No \\
\hline Giczy 2010* & Yes & Yes & Yes & No & No & No \\
\hline Huang 2009-10 & No & No & No & No & No & No \\
\hline
\end{tabular}

* AHA paper 
The experiences of finding the eight full-text papers were highly variable (see Table 2):

- Welker's (2015 AHA award) full text was published as an honors essay in the institutional repository; we are unsure of whether it was identical to the journal publication but gave it the benefit of the doubt. The paper was the first result in Google for both title and keyword searches, and for the keyword search was listed as results 1, 2, 3, 4, and 5. When searching the institutional repository by keyword (Welker Black Power Student Activism North Carolina), it was third-ranked. We were able to find the paper by title in the institutional repository if we modified the title's date range to 1967-1973 instead of 1967-73.

- Antiglio's (2014-2015 WHA award) full text was published on issuu and on the website for Undergraduate Awards, a non-profit organization that recognizes and shares undergraduate work. Initially, the paper was found only on the issuu platform with a Google search on the full title; for one co-author the result ranked 7; for the other coauthor, 9. A month later, the paper was found on the "Undergraduate Awards" website as the top-ranked result for a Google keyword search, linking to an embedded PDF.

- Anbinder's (2014 AHA award) full text was published on the school's journal website (not in the institutional repository). Its ranking varied in Google's top 5, but ranked consistently first in Google Scholar for both title and keyword. In both search engines, the first link led to the CiteSeerX repository's metadata page, which linked to the journal website. Only in Google were links found direct to the PDF on the journal website (as the second link). 
- Wemer's (2013 AHA award) full text was published in the institutional repository (within a journal) and also on semanticscholar.org. The paper ranked first in both Google and Google Scholar for both title and keyword search and also ranked twice more in Google's top five for a keyword search. For the title search in Google, the full-text link went directly to the PDF in the institutional repository. The keyword search in Google first retrieved a record with a link to the institutional repository's PDF; a second link went to the institutional repository PDF directly; and a third link went to a metadata record with a link to the PDF on Semantic Scholar, a search tool for finding academic work. The paper was found in the institutional repository only when using a keyword search; the result link went to the record page of the journal website in the institutional repository, from which full text could be accessed.

- Shah's (2012-2013 WHA award) full text was published on the school's journal website (not in the institutional repository), and was ranked first, second, and third in Google results. It was also ranked first by Google Scholar and Microsoft Academic. The first Google and Google Scholar links led to the abstracts page of the journal site (OJS); in Google, the title search's second link led to an OJS page where a preview of the PDF was available. Google's third link led to the PDF file for the title search and HTML full text for the keyword search. On Google Scholar, a link in Google's right-hand column led to HTML full text. In Microsoft Academic, the first link went to the PDF preview and the second went direct to PDF.

- Kang's (2011-2012 WHA award) full text was published on the journal website inside a 143-page PDF file. It was ranked fourth when using a Google search on the title. One author was also able to find the full text with a Google keyword search. 
- Williford's (2011 AHA award) full text was published on the school's journal website (not in the institutional repository). Only Google found the paper (title and keyword). Google ranked it as the first result and the link went directly to the PDF on the journal website.

- Giczy's (2010 AHA award) full text was published on the school's journal website (not in the institutional repository). It was top-ranked by by Google, Google Scholar, and Microsoft Academic for both title and keyword searches. The top-ranked Google results led to the full text (HTML) on the journal website, while Google's second-ranked result led to the record, where HTML or PDF links could be found. Google Scholar led to the same metadata record page. Microsoft Academic's result offered links first to the PDF, then to the record page. The results with Microsoft Academic were inconsistent; the first author who searched, found it; the second author did not (and the first author verified); but on a later occasion the result re-appeared 
Table 2. Links from search tools to full text of student papers

\begin{tabular}{|c|c|c|c|}
\hline Search tool & First link & Second link & Third link \\
\hline Google title & $\begin{array}{l}\text { Welker - PDF } \\
\text { Antiglio - PDF } \\
\text { Anbinder - metadata } \\
\text { Wemer - PDF } \\
\text { Shah - metadata } \\
\text { Kang - PDF } \\
\text { Williford - PDF } \\
\text { Giczy - HTML }\end{array}$ & $\begin{array}{l}\text { Anbinder - PDF } \\
\text { Shah - PDF embed } \\
\text { Giczy - metadata }\end{array}$ & Shah - PDF \\
\hline Google keyword & $\begin{array}{l}\text { Welker - PDF } \\
\text { Antiglio - PDF embed } \\
\text { Anbinder - metadata } \\
\text { Wemer - metadata } \\
\text { Shah - metadata } \\
\text { Kang - PDF } \\
\text { Williford - PDF } \\
\text { Giczy - HTML }\end{array}$ & $\begin{array}{l}\text { Welker - metadata } \\
\text { Anbinder - PDF } \\
\text { Wemer - PDF } \\
\text { Shah - PDF embed } \\
\text { Giczy - metadata }\end{array}$ & $\begin{array}{l}\text { Welker - search } \\
\text { results page } \\
\text { Wemer - metadata } \\
\text { Shah - HTML }\end{array}$ \\
\hline $\begin{array}{l}\text { Google Scholar } \\
\text { (title and } \\
\text { keyword) }\end{array}$ & $\begin{array}{l}\text { Anbinder - metadata } \\
\text { Wemer - metadata } \\
\text { Shah - metadata } \\
\text { Giczy - metadata }\end{array}$ & $\begin{array}{l}\text { Anbinder - metadata } \\
\text { Wemer - metadata } \\
\text { Shah - HTML }\end{array}$ & Wemer - PDF \\
\hline $\begin{array}{l}\text { Institutional } \\
\text { Repository } \\
\text { (keyword only) }\end{array}$ & $\begin{array}{l}\text { Welker - metadata* } \\
\text { Wemer - metadata }\end{array}$ & & \\
\hline $\begin{array}{l}\text { Microsoft } \\
\text { Academic (title } \\
\text { and keyword) }\end{array}$ & $\begin{array}{l}\text { Shah - PDF embed } \\
\text { Giczy- PDF }\end{array}$ & $\begin{array}{l}\text { Shah - PDF } \\
\text { Giczy - metadata }\end{array}$ & \\
\hline
\end{tabular}

\section{Scholars' Visibility}

None of the authors or the faculty advisors of the AHA papers had ORCIDs or Google Scholar profiles.

\section{Journals}

Fourteen of the 20 institutions in the study had an undergraduate history journal (see Table 3). Initially, 16 undergraduate student history journals were identified, but two of the CUR list's journals returned a 404 error and were removed from the sample. Of these, 13 institutions had repositories, but only three of the journals were substantively included in their institution's repository. For a fourth (Columbia Undergraduate Journal of History), a few articles were 
found. Five of the 14 journals had ISSN numbers, and four were found in Ulrich's; all four in Ulrich's had ISSNs. Five of the six journals in which AHA and WHA award-winners appeared were entirely absent from these scholarly databases and the ISSN list (see Table 3). Only one journal, History Matters: An Undergraduate Journal of Historical Research, was found in both America: History and Life and Historical Abstracts. 
Table 3. The scholarly presence of undergraduate history journals

\begin{tabular}{|c|c|c|c|c|c|c|c|}
\hline Source & Journal Title & ISSN & Ulrich's & $\begin{array}{l}\text { Institutional } \\
\text { Repository }\end{array}$ & $\begin{array}{l}\text { America: } \\
\text { History \& } \\
\text { Life }\end{array}$ & $\begin{array}{l}\text { Historical } \\
\text { Abstracts }\end{array}$ & $\begin{array}{l}\text { Google } \\
\text { Scholar }\end{array}$ \\
\hline CUR & $\begin{array}{l}\text { History Matters: An Undergraduate } \\
\text { Journal of Historical Research }\end{array}$ & $1934-4651$ & Yes & Not Found & $\begin{array}{l}\text { Yes }(32 \\
\text { articles) }\end{array}$ & $\begin{array}{l}\text { Yes }(25 \\
\text { articles })\end{array}$ & 2 articles \\
\hline AHA & Gettysburg Historical Journal & $\begin{array}{l}2327-3917 \\
\text { (online) } \\
2327-3909 \\
\text { (print) }\end{array}$ & Yes & Yes & Not Found & Not Found & Not Found \\
\hline CUR & $\begin{array}{l}\text { Armstrong Undergraduate Journal of } \\
\text { History }\end{array}$ & $2163-8551$ & Yes & NA & Not Found & Not Found & 2 citations \\
\hline CUR & Grand Valley Journal of History & $2381-4411$ & Not Found & Yes & Not Found & Not Found & 30 articles \\
\hline CUR & Tufts Historical Review & $1945-8681$ & Yes & Not Found & Not Found & Not Found & Not Found \\
\hline Google & Perspectives in History & & Not Found & Not Found & Not Found & Not Found & $\begin{array}{l}24 \text { articles; } 1 \\
\text { citation }\end{array}$ \\
\hline CUR & Vanderbilt Historical Review & & Not Found & Yes & Not Found & Not Found & 1 article \\
\hline AHA & Yale Historical Review & & Not Found & Not Found & Not Found & Not Found & $\begin{array}{l}20 \text { articles; } 1 \\
\text { citation }\end{array}$ \\
\hline CUR & $\begin{array}{l}\text { Columbia Undergraduate Journal of } \\
\text { History }\end{array}$ & & Not Found & A few articles & Not Found & Not Found & 1 citation \\
\hline CUR & $\begin{array}{l}\text { Clio's Scroll, the Berkeley } \\
\text { Undergraduate History Journal }\end{array}$ & & Not Found & Not Found & Not Found & Not Found & Not Found \\
\hline WHA & Emory Endeavors in World History & & Not Found & Not Found & Not Found & Not Found & $\begin{array}{l}2 \text { articles, } 1 \\
\text { citation }\end{array}$ \\
\hline AHA & Rhodes Historical Review & & Not Found & Not Found & Not Found & Not Found & Not Found \\
\hline AHA & $\begin{array}{l}\text { Traces: The UNC-Chapel Hill Journal of } \\
\text { History }\end{array}$ & & Not Found & Not Found & Not Found & Not Found & Not Found \\
\hline AHA & $\begin{array}{l}\text { Voces Novae: Chapman University } \\
\text { Historical Review }\end{array}$ & & Not Found & Not Found & Not Found & Not Found & Not Found \\
\hline
\end{tabular}


If these journals weren't generally included in institutional repositories or found using scholarly databases, where were they published and found? Ten of the journals seemed to be hosted on non-institutional repository websites, including the department's web server, a system like OJS, or a WordPress site. A few journals were mirrored across multiple sites; for example Vanderbilt Historical Review appears to be published on WordPress in addition to the institutional repository.

As for finding the journals, Google, Google Scholar, and Facebook were better options than traditional scholarly tools. Twelve of the 14 journals were found as the first result in a Google search on the title. Regarding the first outlier, Google found individual issues from the Rhodes Historical Review, but we did not discover the journal home page. For the final journal, Traces: The UNC-Chapel Hill Journal of History, we found pages about the journal, but no online version of the journal, its issues, or articles. (Just before submission we found Traces has now been restored to online status.) Using Google Scholar's "Return articles published in" feature, results were found for eight of the 14 journals (see Table 4). None of the journals were found in Microsoft Academic using a search on the journal title.

Five of the 14 journals had a Facebook page and these were all updated within the past year; three in April 2017, and two in Fall 2016. Several other journals were mentioned in Facebook posts from a related entity, such as Phi Alpha Theta or the history department (see Table 5). 
Table 4. Undergraduate student history journal visibility in Google Scholar

\begin{tabular}{|c|c|c|c|c|}
\hline Source & Journal Title & Articles & $\begin{array}{l}\text { Citation } \\
\text { Only }\end{array}$ & Notes \\
\hline CUR & $\begin{array}{l}\text { Grand Valley Journal of } \\
\text { History }\end{array}$ & 30 & 0 & $\begin{array}{l}\text { Pub dates ranged from 2012-2017; all from institutional } \\
\text { repository }\end{array}$ \\
\hline AHA & Yale Historical Review & 20 & $\begin{array}{l}1 \text { (no } \\
\text { date) }\end{array}$ & $\begin{array}{l}\text { Articles ranged from 1955-2016; found via journal website } \\
\text { and academia.edu. }\end{array}$ \\
\hline WHA & $\begin{array}{l}\text { Emory Endeavors in World } \\
\text { History }\end{array}$ & 2 & 1 & $\begin{array}{l}\text { Pub dates } 2007 \text { for articles, } 2013 \text { for citation. Articles on } \\
\text { history.emory.edu }\end{array}$ \\
\hline CUR & $\begin{array}{l}\text { History Matters: An } \\
\text { Undergraduate Journal of } \\
\text { Historical Research }\end{array}$ & 2 & 0 & Pub dates 2007, 2011; both from journal website \\
\hline CUR & $\begin{array}{l}\text { Vanderbilt Historical } \\
\text { Review }\end{array}$ & 1 & 0 & Pub date 2017 on Humanities Commons \\
\hline CUR & $\begin{array}{l}\text { Armstrong Undergraduate } \\
\text { Journal of History }\end{array}$ & 0 & 2 & Pub dates 2011, 2013 \\
\hline CUR & $\begin{array}{l}\text { Columbia Undergraduate } \\
\text { Journal of History }\end{array}$ & 0 & 1 & Pub date 2009 \\
\hline Google & Perspectives in History* & 34 & 1 & Pub dates 1988-2008 \\
\hline
\end{tabular}

* We found out about this journal because a paper from its institution won an award from the institution, but the paper itself wasn't in the journal. 
Table 5. Undergraduate student history journal presences on Facebook

\begin{tabular}{|c|c|c|c|}
\hline Source & Journal Title & Facebook Page & $\begin{array}{l}\text { Facebook posts by a related } \\
\text { entity }\end{array}$ \\
\hline CUR & $\begin{array}{l}\text { Clio's Scroll, the Berkeley } \\
\text { Undergraduate History } \\
\text { Journal }\end{array}$ & $\begin{array}{l}\text { Yes; last updated } \\
10 / 31 / 16\end{array}$ & \\
\hline CUR & $\begin{array}{l}\text { Columbia Undergraduate } \\
\text { Journal of History }\end{array}$ & $\begin{array}{l}\text { Yes; Groups page; last } \\
\text { updated } 8 / 5 / 2014\end{array}$ & \\
\hline CUR & $\begin{array}{l}\text { Grand Valley Journal of } \\
\text { History }\end{array}$ & $\begin{array}{l}\text { Yes; last updated } \\
12 / 4 / 2016\end{array}$ & \\
\hline CUR & Tufts Historical Review & $\begin{array}{l}\text { Yes; last updated } \\
4 / 3 / 17\end{array}$ & \\
\hline CUR & $\begin{array}{l}\text { Vanderbilt Historical } \\
\text { Review }\end{array}$ & $\begin{array}{l}\text { Yes; last updated } \\
4 / 25 / 17\end{array}$ & \\
\hline AHA & Yale Historical Review & $\begin{array}{l}\text { Yes; last updated } \\
4 / 19 / 17\end{array}$ & \\
\hline AHA & Rhodes Historical Review & Not Found & $\begin{array}{l}\text { History department posted a } \\
\text { call for papers } 4 / 28 / 17\end{array}$ \\
\hline AHA & $\begin{array}{l}\text { Traces: The UNC-Chapel } \\
\text { Hill Journal of History }\end{array}$ & Not Found & $\begin{array}{l}\text { History department posted a } \\
\text { call for papers } 5 / 19 / 17\end{array}$ \\
\hline AHA & $\begin{array}{l}\text { Voces Novae: Chapman } \\
\text { University Historical } \\
\text { Review }\end{array}$ & Not Found & $\begin{array}{l}\text { Phi Alpha Theta announced } \\
\text { the journal's new issue } 7 / 5 / 17\end{array}$ \\
\hline CUR & $\begin{array}{l}\text { Armstrong Undergraduate } \\
\text { Journal of History }\end{array}$ & Not Found & \\
\hline WHA & $\begin{array}{l}\text { Emory Endeavors in } \\
\text { World History }\end{array}$ & Not Found & \\
\hline $\begin{array}{l}\text { AHA; } \\
\text { CUR }\end{array}$ & $\begin{array}{l}\text { Gettysburg Historical } \\
\text { Journal }\end{array}$ & Not Found & \\
\hline CUR & $\begin{array}{l}\text { History Matters: An } \\
\text { Undergraduate Journal of } \\
\text { Historical Research }\end{array}$ & Not found & \\
\hline Google & Perspectives in History & Not Found & \\
\hline
\end{tabular}




\section{Repositories}

Our initial method of searching for the journal title in the repository search box turned out to be insufficient for determining if a repository contained a journal. After marking the Grand Valley History Journal as Not Found in its repository, we noticed the repository's selfdescription mentioned the journal. Upon further investigation, we found that while articles in the journal could be found in the repository, neither the main search box nor the advanced search were useful for searching for the journal title. A bePress representative confirmed this situation: “In Digital Commons, the title of a work's structure (the journal, series, etc) is not included in the fields that are searched in a simple search. A simple search for the structure's title may still return works within the structure for works that include the structure's title elsewhere in the metadata or in the document's full text" (Benedek Nyikos, email communication to author, September 11, 2017). To verify whether the repository contained the journal, we therefore also browsed the repository's collections and series, looking for collections such as "History Department" and "Student Works."

As mentioned earlier, only two of the 15 award-winning papers appeared in their repositories, and three of the 14 journals appeared in their institution's repositories. In several cases, the repository featured other student publications and journals, just not the history journal.

\section{Discussion}

Overall, our study suggests the discoverability of undergraduate history research is limited and that it is more discoverable on the public web than within the scholarly network. This finding is upheld across our samples of papers, journals, scholars, and repositories. We see opportunities for libraries to expand their communication, educational, and promotional efforts 
on campus to foster the wider dissemination of undergraduate research and the place of undergraduate scholars as part of the larger scholarly network.

The undergraduate research papers in our sample were most often retrieved by Google. Fagan's (2017) literature review found that Google can often retrieve scholarly work that Google Scholar fails to find. Our study supports this: four of the 15 papers in the sample were found using Google but not Google Scholar, including one published in an institutional repository. Only two of the papers were contained in their institution's repository. There were several cases where our search experience varied over time. For Antiglio (2014-2015 WHA award), the paper rose in ranking from 9 to 7 to 1 from July $9^{\text {th }}$ to August $9^{\text {th }}$. This could be due to the paper's visibility on the Undergraduate Awards website. We experienced other fluctuations in results ranking even within this small sample. Giczy (2010 AHA award) was initially found in Microsoft Academic in early June, then disappeared (verified by both authors) only to re-appear a month later.

The discoverability of undergraduate research is further limited by the lack of student presence in academic databases and scholarly profiles, which may be influenced by the faculty they work with: none of the students or faculty mentors had an ORCID or Google Scholar profile. None of the papers appeared in the two library databases.

Undergraduate student journals had a greater presence on Facebook than in the traditional scholarly network. Only four of the fourteen journals in our study had entries in Ulrich's Periodical Directory; four were present in their institution's repository; three were meaningfully included in Google Scholar, and just one was included in America: History and Life and Historical Abstracts. We reached out to EBSCO's editorial team and Beverly Pager, Academic Product Manager for EBSCO Information Services, explained their general editorial policy was 
to continue with ABC-Clio's practice of indexing primarily peer-reviewed journal titles, "thus, it hasn't been our policy overall to add titles with solely student-researched content" (Email communication to author, September 14, 2017). She was interested in learning more about librarians' perspectives about the research value of including student publications, but noted some of the issues included the level of scholarship (peer review process; general oversight and quality); irregularity in publishing and who to contact; multidisciplinarity (thus not suitable for subject-specific databases); difficulty in locating titles; value to the academic market; and the format of content (online, pdf, print, etc.). Furthermore, Pager noted that many of their customers have purchasing guidelines concerning the percentage of open access in any given database. "While we don't charge extra for this content, it does factor into our title list counts" (Email communication to author, September 18, 2017). Despite these challenges, she welcomed librarians to submit titles for the EBSCO team to consider for inclusion.

The irregularity of undergraduate journals may also be an issue. Of the journals found because they had award-winning student papers, only the Gettysburg Historical Journal was included on CUR's journals list (http://www.cur.org/resources/students/undergraduate_journals/), while two history journals on that list could no longer be retrieved (Foundations and Women's Web Work).

Only two papers were found in their institution's repository in our sample. Of those institutions lacking their students' award-winning work, many did contain other studeRnt publication series and student journals, suggesting their missions do include publicizing undergraduate research. For example, Chapman University’s Economic Science Institute publishes e-Research: A Journal of Undergraduate Work in the repository, but the History department only offers history faculty publications. Ursinus College’s repository includes 
student research from the history department ("History Honors Papers" and "History Summer Fellows" collections), just not the student journal. Perhaps the issue is just lack of knowledge and proactive communication across the institution: In response to a query from one of the authors, the editor of Traces expressed interest in being included in the Carolina Digital Repository, but wasn't sure how to proceed (Garrett Wright, email message to author, September 10, 2017). In response to a query about the fate of Foundations, an erstwhile history journal at Johns Hopkins University, the faculty advisor mentioned the need for technical support, and another faculty member chimed in to suggest he contact the librarian liaison to history (Jeffrey Brooks and Michael Kwass, email messages to author, September 10, 2017).

Gettsyburg College could serve as a model for making undergraduate research visible. Their repository's "Student Publications" collection includes papers from 2010-2017, and the “Journals" collection contains four student journals (two for history) and one literary magazine (http://cupola.gettysburg.edu/peer_review_list.html ). As of July 29, 2017, the 122 student papers from the Gettysburg Historical Journal had collectively been downloaded 23,142 times in the past year. (There is ongoing discussion about the validity of download counts using different methods; see Arlitsch and Mixter 2017; Obrien et al. 2016.) Searching for the top ten mostdownloaded journal articles found that each was only cited a few times in Google Scholar, if at all, but the papers had proved useful: "The Tavern in Colonial America" had been cited by another student paper and a historical association newsletter that focused on a family's taverns across Pennsylvania. The student paper "Voices of Moderation: Southern Whites Respond to Brown v. Board of Education" was cited by a thesis and a dissertation. We also searched for these ten papers in Google Books: One paper was cited by the Yearbook of the Research Centre for German and Austrian Exile Studies (Atkins 2005). 
Janelle Wertzberger, Assistant Dean and Director of Scholarly Communications at Gettysburg, said the library took the initiative to put The Gettysburg Historical Journal into the repository, which was launched in 2012. Both the library and history department were eager to share the students' scholarship more broadly, and uploaded the entire backfile (Email communication to author, September 15, 2017). She described the effort as "easy to sustain" since there is only one issue per year. The library works closely with the student editors as well as the faculty advisor. No specific effort is required to ensure articles are indexed in Google; the SEO of the bePress Digital Commons platform takes care of that.

Academic digital libraries and search engines like CiteSeerX can play a role in discovery. For example, the most prominent links to Anbinder (2014 AHA award) went to CiteSeerX, which then linked to the full text. Although direct links to full text were found in Google, they were lower-ranked, and there would have been no pathway to the Anbinder paper in Google Scholar were it not for CiteSeerX. Platforms like ResearchGate, Academia.edu, and Semantic Scholar also seem to play a role even when it's not clear why they do. For one of the student papers, Wemer (2013 award), Google found the full text on Semantic Scholar as well as in the institution's repository. The description of Semantic Scholar provides no clue about why a student history paper would be included; it is said to include content from arXiv, the dblp computer science bibliography, CiteSeerX, OdySci Academic, and AMiner.

Our study found few patterns in whether search tools ranked PDFs or metadata records more highly. Google ranked PDF more highly six out of eight times for title searches, and five out of eight times for keyword searches. Google Scholar linked to metadata records for all four of the full-text articles it found; when it linked to PDF or HTML, these links were ranked lower in the results list. The results link for both articles found in the institutional repository went to the 
metadata record, while in Microsoft Academic, results links went to PDF for both articles. An obvious advantage to linking direct to PDF is expediency, but PDFs can the lack information necessary for full citation, and don't provide navigation pathways to the journals or sites which contain them.

\section{Recommendations}

As discussed in the literature review, libraries are already involved in supporting undergraduate research. To further improve dissemination, we see growth opportunities for librarians and libraries in communication, outreach, and education related to the dissemination and discoverability of undergraduate papers, journals, academic identities, and repositories. Undergraduates are becoming recognized as emergent authors (Caprio 2014) and academic libraries are often well-positioned to facilitate undergraduate publication through their expertise, services, infrastructures, and partnerships (Weiner and Watkinson 2014).

Institutional repositories could play a stronger role in making undergraduate research more consistently discoverable. First, system administrators and software developers need to prioritize structuring repositories for discovery by web search engines. Our study's findings support Yang's (2016a) research showing search engines are still struggling to discover PDFs and sometimes metadata in institutional repositories. The Carolina Digital Repository noted their current platform is not optimized for Google Scholar because it does not contain the necessary tags. They are planning to migrate to a new system that will better support Google and Google Scholar (Julie Rudder, email communication to author, September 11, 2017).

There are examples of librarians serving as managers or collaborative managers of undergraduate research journals (Farney and Byerley 2010; Weiner and Watkinson 2014; Johnson, Mears, and Drescher 2017), but even where involvement is more limited, scholarly 
communication librarians and subject librarians can serve as informal advisors on campus to student journals, summer fellowship programs, and award programs, building bridges for undergraduate research to travel from academic departments to institutional repositories. Libraries and librarians can also help with the process of getting student journals included in the local institutional repository and Ulrich's Periodical Directory and acquiring ISSNs and DOIs. The details of becoming indexed by Google Scholar are publicly available (Google 2017) and librarians could suggest their local journals' websites present content using standard SEO techniques (Onaifo and Rasmussen 2013). When working with a student journal that has a proven track record, librarians can also encourage abstract and index vendors, such as EBSCO, to include specific undergraduate journals, perhaps suggesting policies based on quality and consistency of publication.

An undergraduate research training program at the University of Tennessee, Knoxville teaches students about outlets for sharing their work, including academic publications and institutional repositories (Douglass and Mack 2015). Librarians and teaching faculty could include information about publishing opportunities in relevant library instruction classes. More libraries could include students in their vision for and programming related to scholarly communication. Social media has been shown to increase the visibility of scholars and their works (Bik and Goldstein 2013), as have scholarly profiles (Bar-Ilan et al. 2012; Mas-Bleda et al. 2014) and scholarly identifiers (Swiontkowski 2016). Plenty of libraries engage in communication efforts to promote Google Scholar profiles, scholarly identifiers, or both (Ebrahim 2016; Schubert and Holloway 2014; Swiontkowski 2016; Vàllez 2017). Akers et al. (2016) have enumerated many examples of library outreach efforts related to promoting ORCIDs (see also Rosenzweig 2017). Such efforts could be expanded to include undergraduates, perhaps 
reaching out to editors of undergraduate journals as a target audience. Structures such as capstone courses, summer fellowships, and prizes also offer the means of identifying students who have the interest and ability to take their research beyond the classroom into published scholarship.

\section{Future Research}

This study revealed several opportunities for further research in this area. We specifically examined the web visibility of award-winning articles by undergraduates in the field of history. Similar studies of other disciplines could be carried out, allowing librarians to create more customized support for students pursuing different majors. A broader study of the web visibility of undergraduate work in a variety of formats would also further inform efforts of academic libraries to support students as participants in creative and scholarly communities. We focused on student papers, but undergraduate research is increasingly presented in other formats, such as digital projects (e.g., Stephens and Thumma 2005; Johnson and Harreld 2012). Curating digital projects in a way that supports dissemination and promotion of student research is new territory for academia. To what extent are these projects discoverable, and what strategies (e.g. SEO, linked data, social media) are most successful?

This study's sample of student scholars and their advisors was small, but pointed to a dearth of history scholars in academic identity databases such as ORCID and scholarly profile databases such as Google Scholar. Research could be conducted to more rigorously measure the presence of humanities scholars in scholarly profile and identifier databases. A locally-focused effort to do so before and after a major campus educational effort concerning scholarly communication could help measure the effectiveness of the initiative. 
Finally, this study took the approach of searching for student papers, scholars, and journals by brute force. However, we are confident the stories behind the scenes would add valuable qualitative information for further diagnosing communication gaps and identifying solutions. Case study or survey research with academic departments, student journal editors, faculty advisors, and the like by academic librarians could add richness to our professional understanding of undergraduate student publications.

\section{Conclusion}

With the increase in institutional interest concerning undergraduate research as a highimpact practice, librarians and libraries have a golden opportunity to further develop their roles as strategic partners. Humanists, and particularly historians, may need a little extra encouragement or education regarding how to move undergraduate research into the scholarly network. As more faculty come to recognize student research as part of the institution's scholarly output, librarians can be ready to show how student research can be included in local scholarly spaces like institutional repositories and in abstracts and indexes. Librarians also have direct channels to students, who can benefit from information about the potential for their research to be more discoverable on the web. Developing a holistic approach to making undergraduate research more visible involves continued attention to institutional structures as well as individual education and support. 


\section{Bibliography}

Akers, Katherine G., Alexandra Sarkozy, Wendy Wu, and Alison Slyman. 2016. "ORCID Author Identifiers: A Primer for Librarians.” Medical Reference Services Quarterly 35 (2): 135-144. https://doi.org/10.1080/02763869.2016.1152139 .

American Historical Association. 2017. "Raymond J. Cunningham Prize Recipients. https://www.historians.org/awards-and-grants/past-recipients/raymond-j-cunninghamprize-recipients

Arlitsch, Kenning, and Jeff Mixter. 2017. "Works in Progress Webinar: More Accurately Measuring Item Downloads from Institutional Repositories.” OCLC Research, July 6. http://www.oclc.org/research/events/2017/07-06.html

Arlitsch, Kenning, and Patrick S. O’Brien. 2012. "Invisible Institutional Repositories: Addressing the Low Indexing Ratios of IRs in Google Scholar.” Library Hi Tech 30 (1): 60-81. https://doi.org/10.1108/07378831211213210 .

Association of American College \& Universities. 2008. "High-Impact Educational Practices." Accessed October 1, 2017. https://www.aacu.org/leap/hips.

Atkins, Elizabeth. 2005. “'You Must All be Interned': Identity Among Internees in Great Britain during World War II." Gettysburg Historical Journal 4(5). http://cupola.gettysburg.edu/ghj/vol4/iss1/5/

Bar-Ilan, Judit, Stefanie Haustein, Isabella Peters, Jason Priem, Hadas Shema, and Jens Terliesner. 2012. "Beyond Citations: Scholars' Visibility on the Social Web." ArXiv Preprint arXiv:1205.5611. 
Bik, Holly M., and Miriam C. Goldstein. 2013. "An Introduction to Social Media for Scientists." PLoS Biology 11 (4): e1001535. https://doi.org/10.1371/journal.pbio.1001535.

Boyer Commission on Educating Undergraduates in the Research University. 1998. Reinventing Undergraduate Education: A Blueprint for America's Research Universities. Princeton, NJ: Carnegie Foundation for the Advancement of Teaching.

Caprio, Mark J. 2014. "Student Publishing: Future Scholars as Change Agents.” OCLC Systems \& Services 30 (3): 144-157. https://doi.org/10.1108/OCLC-01-2014-0003.

Cook, Matthew. 2015. "Build it and They Will Come: Integrating Unique Collections and Undergraduate Research.” Collection Building 34 (4): 128-133. https://doi.org/10.1108/CB-06-2015-0010 .

Corley, Christopher R. 2013. "From Mentoring to Collaborating: Fostering Undergraduate Research in History." History Teacher 46 (3): 397-414.

Council on Undergraduate Research. n.d. "About the Council on Undergraduate Research." Accessed October 1, 2017. http://www.cur.org/about_cur

Crawford, Iain, and Jenny Olin Shanahan. 2014. "Undergraduate Research and Creative Activity in the Arts and Humanities: Challenge, Opportunities, and Rewards." In How to Get Started in Arts and Humanities Research with Undergraduates, edited by Iain Crawford, Sara E. Orel, and Jenny Olin Shanahan, 1-11. Washington, DC: Council on Undergraduate Research.

Dagienè, Eleonora, and Danutė Krapavickaitè. 2016. "How Researchers Manage their Academic Activities." Learned Publishing. 29 (3): 155-163. https://doi.org/10.1002/leap.1030 . 
Daniel, Dominique. 2012. "Teaching Students how to Research the Past: Historians and Librarians in the Digital Age." History Teacher 45 (2): 261-282.

Davis-Kahl, Stephanie. 2012. "Engaging Undergraduates in Scholarly Communication.” College \& Research Libraries News 73 (4): 212-222.

Douglass, Kimberly, and Thura Mack. 2015. "What Do You Give the Undergraduate Researcher Who has Everything? An Academic Librarian.” Journal of Academic Librarianship 41 (5): 540-547. https://doi.org/10.1016/j.acalib.2015.07.008.

Ebrahim, Nader Ale. 2016. Create a Google Scholar Profile to Increase Research Visibility. https://doi.org/10.6084/m9.figshare.4214274.v1 .

Ebrahim, Nader Ale, Hadi Salehi, Mohamed Amin Embi, Farid Habibi, Hossein Gholizadeh, Seyed Mohammad Motahar, and Ali Ordi. 2013. "Effective Strategies for Increasing Citation Frequency.” International Education Studies 6 (11): 93-99. https://ssrn.com/abstract=2344585.

Fagan, Jody C. 2017. “An Evidence-Based Review of Academic Web Search Engines, 20142016: Implications for Librarians’ Practice and Research Agenda.” Information Technology and Libraries 36 (2). https://doi.org/10.6017/ital.v36i2.9718 .

Farney, Tabatha A., and Suzanne L. Byerley. 2010. "Publishing a Student Research Journal: A Case Study." portal: Libraries \& the Academy 10 (3): 323-335.

Fraser Riehle, Catherine, and Merinda Kaye Hensley. 2017. "What Do Undergraduate Students Know about Scholarly Communication? A Mixed Methods Study.” portal: Libraries \& the Academy 17 (1): 145-178. 
Galgano, Michael J., J. Chris Arndt, and Raymond M. Hyser. 2013. Doing History: Research and Writing in the Digital Age. Boston: Wadsworth Cengage Learning.

Gasparotto, Melissa. 2014. "Search Engine Optimization for the Research Librarian: A Case Study using the Bibliography of U.S. Latina Lesbian History and Culture.” Practical Academic Librarianship: The International Journal of the SLA Academic Division 4 (1): 15-34. https://journals.tdl.org/pal/index.php/pal/article/view/6971 .

Google, Inc. 2017. "Inclusion Guidelines for Webmasters." https://scholar.google.com/intl/en/scholar/inclusion.html

Gumpenberger, Christian, Johannes Sorz, Martin Wieland, and Juan Gorraiz. 2016. “Humanities in the Bibliometric Spotlight-Research Output Analysis at the University of Vienna and Considerations for Increasing Visibility.” Research Evaluation 25 (3): 271-278. https://doi.org/10.1093/reseval/rvw013

Hammarfelt, Björn. 2014. "Using Altmetrics for Assessing Research Impact in the Humanities." Scientometrics 101 (2): 1419-1430.

—. 2016. "Beyond Coverage: Toward a Bibliometrics for the Humanities." In Research Assessment in the Humanities, 115-131. Switzerland: Springer International.

Harbinson, Thomas, and Luke Waltzer. 2013. "Toward Teaching the Introductory Course, Digitally." In Writing History in the Digital Age, edited by Jack Dougherty and Kristen Nawrotzki, 97-109. Ann Arbor: The University of Michigan Press.

Hensley, Merinda Kaye. 2015. “A Survey of Instructional Support for Undergraduate Research Programs." portal: Libraries \& the Academy 15 (4): 719-746. 
Hensley, Merinda Kaye, Sarah L. Shreeves, and Stephanie Davis-Kahl. 2014. “A Survey of Library Support for Formal Undergraduate Research Programs.” College \& Research Libraries 75 (4): 422-441. https://doi.org/10.5860/crl.75.4.422 .

Hicks, Alison, and Adrian Howkins. 2015. "Tipping the Iceberg: A Collaborative LibrarianHistorian Approach to Redesigning the Undergraduate Research Assignment.” History Teacher 48 (2): 339-359.

Hilliker, Robert J., Melanie Wacker, and Amy L. Nurnberger. 2013. “Improving Discovery of and Access to Digital Repository Contents using Semantic Web Standards: Columbia University’s Academic Commons.” Journal of Library Metadata 13 (2-3): 80-94. https://doi.org/10.1080/19386389.2013.826036 .

Inger, Simon, and Tracy Gardner. 2016. "How Readers Discover Content in Scholarly Publications.” Information Services \& Use 36 (1): 81-97. https://doi.org/10.3233/ISU$\underline{160800}$.

Johnson, Benjamin A., and Donald J. Harreld. 2012. "Nurturing Independent Learning in the Undergraduate Student in History: A Faculty-Student Mentoring Experience.” Mentoring \& Tutoring: Partnership in Learning 20 (3): 361-378. https://doi.org/10.1080/13611267.2012 .

Johnson, Melissa E., Kim Mears, and Abigail Drescher. 2017. "Creating the Arsenal: Augusta University’s Undergraduate Research Journal.” Serials Librarian 72 (1-4): 128-133. https://doi.org/10.1080/0361526X.2017.1297590 .

Jones, Kathleen W., Mark V. Barrow, Robert P. Stephens, and Stephen O’Hara. 2012. "Romancing the Capstone: National Trends, Local Practice, and Student Motivation in 
the History Curriculum.” Journal of American History 98 (4): 1095-1113. https://doi.org/10.1093/jahist/jar538.

Katkin, Wendy. 2003. "The Boyer Commission Report and its Impact on Undergraduate Research.” New Directions for Teaching \& Learning 2003 (93): 19.

Kemman, Max, Martijn Kleppe, and Stef Scagliola. 2013. "Just Google it-Digital Research Practices of Humanities Scholars.” ArXiv Preprint arXiv:1309.2434.

Lawrence, Adrea. 2013. "Learning How to Write Analog and Digital History.” In Writing History in the Digital Age, edited by Jack Dougherty and Kristen Nawrotzki, 110-120. Ann Arbor: The University of Michigan Press.

Lee, Sungin, Wonhong Jang, Eunsol Lee, and Sam G. Oh. 2016. "Search Engine Optimization: A Case Study using the Bibliographies of LG Science Land in Korea." Library Hi Tech 34 (2): 197-206. https://doi.org/10.1108/LHT-02-2016-0014.

Martin, Kim, and Anabel Quan-Haase. 2016. “The Role of Agency in Historians' Experiences of Serendipity in Physical and Digital Information Environments.” Journal of Documentation 72 (6): 1008-1026. https://doi.org/10.1108/JD-11-2015-0144 .

Mas-Bleda, Amalia, Mike Thelwall, Kayvan Kousha, and Isidro F. Aguillo. 2014. "Do Highly Cited Researchers Successfully use the Social Web?” Scientometrics 101 (1): 337-356.

Obrien, Patrick, Kenning Arlitsch, Leila Sterman, Jeff Mixter, Jonathan Wheeler, and Susan Borda. 2016. "Undercounting File Downloads from Institutional Repositories.” Journal of Library Administration. 56 (7): 854-874. https://doi.org/10.1080/01930826.2016.1216224 
Onaifo, Daniel, and Diane Rasmussen. 2013. 'Increasing Libraries' Content Findability on the Web with Search Engine Optimization.” Library Hi Tech 31 (1): 87-108. https://doi.org/10.1108/07378831311303958

Pitol, Scott, and Sandra L. De Groote. 2014. "Google Scholar Versions: Do More Versions of an Article Mean Greater Impact?” Library Hi Tech 32 (4): 594-611. https://doi.org/0.1108/LHT- 05-2014-0039 .

Presnell, Jenny L. 2013. The Information-Literate Historian: A Guide to Research for History Students. New York: Oxford University Press.

Rosenzweig, Merle. 2017. Growing ORCID at the University of Michigan. University of Michigan. https://deepblue.lib.umich.edu/handle/2027.42/136642

Schubert, Carolyn, and Steven W. Holloway. 2014. "Give Yourself an ORCID: Boosting Your Visibility through Researcher Profiling Networks." Presentation completed at the 2014 Center for Faculty Innovation May Symposium, Harrisonburg, VA. http://commons.lib.jmu.edu/letfspubs/8/ .

Spronken-Smith, Rachel, Jason J. Brodeur, Tara Kajaks, Martin Luck, Paula Myatt, An Verburgh, Helen Walkington, and Brad Wuetherick. 2013. "Completing the Research Cycle: A Framework for Promoting Dissemination of Undergraduate Research and Inquiry.” Teaching \& Learning Inquiry: The ISSOTL Journal 1 (2): 105-118. https://doi.org/10.2979/teachlearninqu.1.2.105.

Stamatoplos, Anthony. 2009. "The Role of Academic Libraries in Mentored Undergraduate Research: A Model of Engagement in the Academic Community." College \& Research Libraries 70 (3): 235-249. https://doi.org/10.5860/0700235. 
Steele, Tom, and Nicole Sump-Crethar. 2016. "Metadata for Electronic Theses and Dissertations: A Survey of Institutional Repositories." Journal of Library Metadata 16 (1): 53-68. https://doi.org/10.1080/19386389.2016.1161462.

Stephens, Robert P., Kathleen W. Jones, and Mark V. Barrow. 2011. "The Book Project: Engaging History Majors in Undergraduate Research.” History Teacher 45 (1): 65-80.

Stephens, Robert, and Josh Thumma. 2005. "Faculty-Undergraduate Collaboration in Digital History at a Public Research University.” History Teacher 38 (4): 525-542.

Stone, Sean M., and M. Sara Lowe. 2014. "Who is Citing Undergraduate Theses in Institutional Digital Repositories? Implications for Scholarship and Information Literacy." College \& Undergraduate Libraries 21 (3): 345-359. https://doi.org/10.1080/10691316.2014.929065.

Sugimoto, Cassidy R., Sam Work, Vincent Larivière, and Stefanie Haustein. 2017. "Scholarly Use of Social Media and Altmetrics: A Review of the Literature." Journal of the Association for Information Science and Technology 68 (9): 2037-2062. https://doi.org/10.1002/asi.23833.

Swiontkowski, Marc. 2016. “ORCID Registration Required in 2017.” Journal of Bone \& Joint Surgery 98 (24): 2035. https://doi.org/10.2106/JBJS.16.01165.

Vàllez, Mari. 2017. "How to Increase the Visibility of Scientific Articles.” http://openaccess.uoc.edu/webapps/o2/bitstream/10609/64288/1/How\%20to\%20increase $\%$ 20the $\% 20$ visibility $\% 20$ of $\% 20$ scientific $\% 20$ articles.pdf . 
Van Noorden, Richard. 2014. "Online Collaboration: Scientists and the Social Network.” Nature 512 (7513): 126-129. https://doi.org/10.1038/512126a .

Wang, Xiaocan, Natalie Bulick, and Valentine Muyumba. 2014. "Publishing Student Scholarship: Exploring the ETD Initiative at a Medium-Sized Institution.” OCLC Systems \& Services: International Digital Library Perspectives 30 (4): 232-248. https://doi.org/10.1108/OCLC-02-2014-0008 .

Ward, Judit, William Bejarano, and Anikó Dudás. 2015. “Scholarly Social Media Profiles and Libraries: A Review.” Liber Quarterly 24 (4):174-204. https://doi.org/10.18352/lq.9958.

Weiner, Sharon, and Charles Watkinson. 2014. "What Do Students Learn from Participation in an Undergraduate Research Journal? Results of an Assessment.” Journal of Librarianship and Scholarly Communication 2 (2). https://doi.org/10.7710/2162$\underline{3309.1125}$

Wertheimer, John. 2002. “The Collaborative Research Seminar.” Journal of American History 88 (4): 1476-1481.

Wiebe, Todd J. 2016. "The Library and Undergraduate Research in the Liberal Arts: Present Contributions and Future Opportunities." College \& Undergraduate Libraries 23 (3): 223-251. https://doi.org/10.1080/10691316.2015.1016196.

World History Association. 2017. "WHA Awards.” http://www.thewha.org/whaawards/competition-for-undergraduate-graduate-students/whaphi-alpha-thetaundergraduate-and-graduate-student-paper-prize/ 
Wu, Shuheng, Besiki Stvilia, and Dong Joon Lee. 2017. "Readers, Personal Record Managers, and Community Members: An Exploratory Study of Researchers' Participation in Online Research Information Management Systems.” Journal of Library Metadata 17 (2):1-34. https://doi.org/10.1080/19386389.2017.1348783.

Yang, Le. 2016a. "Making Search Engines Notice: An Exploratory Study on Discoverability of DSpace Metadata and PDF Files.” Journal of Web Librarianship 10 (3): 147-160. https://doi.org/10.1080/19322909.2016.1172539. .2016b. "Metadata Effectiveness in Internet Discovery: An Analysis of Digital Collection Metadata Elements and Internet Search Engine Keywords." College \& Research Libraries 77 (1): 7-19. https://doi.org/10.5860/crl.77.1.7 .

Zuccala, Alesia. 2016. "Inciting the Metric Oriented Humanist: Teaching Bibliometrics in a Faculty of Humanities.” Education for Information 32 (2): 149-164. https://doi.org/10.3233/EFI-150969. 


\section{Appendix: Bibliography of Award-Winning Student Papers}

Anbinder, Jacob. 2013. "The South Shall Ride Again: The Origins of MARTA and the Making of the Urban South," Yale Historical Review 2, no. 3 (Spring): 37-57. http://historicalreview.yale.edu/sites/default/files/yhr_spring_2013_web.pdf . Winner of the 2014 AHA Raymond J. Cunningham Prize.

Antiglio, Emilia. 2016. “The Diffusion of Porcelaine des Indes in Eighteenth-Century France: From Lorient to Paris and Beyond, 1720 - 1775." http://www.undergraduatelibrary.org/2016/history/diffusion-porcelaine-des-indeseighteenth-century-france-lorient-paris-and-beyond-1720 . Winner of the 2014-2015 WHA/Phi Alpha Theta Undergraduate \& Graduate Student Paper Prize.

Creech, Griffin. 2016. “'Our Revolutionary Cadres Are Always beside the Masses”:

Reconsidering the Role of Khmer Rouge Cadres in Democratic Kampuchea." Traces: The UNC Chapel Hill Journal of History (Spring): n.p. Winner of the 2016 AHA Raymond J. Cunningham Prize.

Giczy, Hailey. 2009. "The Bum Blockade: Los Angeles and the Great Depression.” Voces Novae: Chapman University Historical Review 1: 97-121. http://journals.chapman.edu/ojs/index.php/VocesNovae/article/view/20 . Winner of the 2010 AHA Raymond J. Cunningham Prize.

Hood, Nathanael Cameron. n.d. "The Roots of Mahayana Buddism.” [sic] Unpublished manuscript. Winner of the 2010-2011 WHA/Phi Alpha Theta Undergraduate \& Graduate Student Paper Prize. 
Huang, Samantha. n.d. “Technologies of Chinese Smuggling: Migratory Knowledge and Networks, 1882-1924." Unpublished manuscript. Winner of the 2009-2010 WHA/Phi Alpha Theta Undergraduate \& Graduate Student Paper Prize.

Kang, Hyeok Hweon. n.d. "Big Heads and Buddhist Demons: The Korean Military Revolution and The Northern Expeditions of 1654 and 1658." Emory Endeavors 4: n.p. http://history.emory.edu/home/documents/endeavors/volume4/EmoryEndeavors4Comple te.pdf . Winner of the 2011-2012 WHA/Phi Alpha Theta Undergraduate \& Graduate Student Paper Prize.

Mscichowski, Jakub. n.d. "From Avalokitesvara to Guanyin and the Maria Kannon: Charting the Roles of Syncretism in East Asian Christianities." Unpublished manuscript. Winner of the 2013-2014 WHA/Phi Alpha Theta Undergraduate \& Graduate Student Paper Prize.

Schrottman, Rachel. n.d. "Francafrique: The French Role in Rwanda." Unpublished manuscript. Winner of the 2016-2017 WHA/Phi Alpha Theta Undergraduate \& Graduate Student Paper Prize.

Shah, Priya. 2013. "Language, Discipline, and Power: The Extirpation of Idolatry in Colonial Peru and Indigenous Resistance" Voces Novae: Chapman University Historical Review 5 (1): n.p. http://journals.chapman.edu/ojs/index.php/VocesNovae/article/view/635 . Winner of the 2012-2013 WHA/Phi Alpha Theta Undergraduate \& Graduate Student Paper Prize.

Valone, T. Fielder. 2012. "Destroying the Ties that Bind: Rituals of Humiliation and the Holocaust in Provincial Lithuania." Traces: The UNC-Chapel Hill Journal of History. 1 (Spring): 90-114. Winner of the 2012 AHA Raymond J. Cunningham Prize. 
Wallin, Matthew. n.d. "Intellectual Crosscurrents of the Black Atlantic: Pan Africanism and Civil Rights in the Time of the Cold War." Unpublished manuscript. Winner of the 20132014 WHA/Phi Alpha Theta Undergraduate \& Graduate Student Paper Prize.

Welker, Michael. 2014. "Nothing without a Demand: Black Power and Student Activism on North Carolina College Campuses, 1967-73." Traces: The UNC-Chapel Hill Journal of History (Spring): 1-79. https://cdr.lib.unc.edu/indexablecontent/uuid:bc11a4ef-cd524aa4-aa02-5200a20148ef Winner of the 2015 AHA Raymond J. Cunningham Prize.

Wemer, David. 2013. “Europe's Little Tiger? Reassessing Economic Transitions in Slovakia under the Meciar Government, 1993-98." Gettysburg College Historical Journal 12 (1): 97-112. http://cupola.gettysburg.edu/ghj/vol12/iss1/7/ . Winner of the 2013 AHA Raymond J. Cunningham Prize.

Williford, Daniel. 2011. "Visions of Pre-Islamic Algeria in the Revue Africaine, 1870-1896," Rhodes Historical Review 13 (Spring): 45-69. https://www.rhodes.edu/sites/default/files/RHR_Volume_13_Spring_2011.pdf . Winner of the 2011 AHA Raymond J. Cunningham Prize. 